University of Nebraska - Lincoln

DigitalCommons@University of Nebraska - Lincoln

Publications from USDA-ARS / UNL Faculty

U.S. Department of Agriculture: Agricultural

Research Service, Lincoln, Nebraska

2014

Micromesh Fabric Pollination Bags for Switchgrass

\author{
Kenneth P. Vogel \\ University of Nebraska-Lincoln, kvogel1@unl.edu \\ G. Sarath \\ USDA-ARS, Gautam.sarath@ars.usda.gov \\ R. B. Mitchell \\ USDA-ARS, rob.mitchell@ars.usda.gov
}

Follow this and additional works at: https://digitalcommons.unl.edu/usdaarsfacpub

Vogel, Kenneth P.; Sarath, G.; and Mitchell, R. B., "Micromesh Fabric Pollination Bags for Switchgrass" (2014). Publications from USDA-ARS / UNL Faculty. 1975.

https://digitalcommons.unl.edu/usdaarsfacpub/1975

This Article is brought to you for free and open access by the U.S. Department of Agriculture: Agricultural Research Service, Lincoln, Nebraska at DigitalCommons@University of Nebraska - Lincoln. It has been accepted for inclusion in Publications from USDA-ARS / UNL Faculty by an authorized administrator of DigitalCommons@University of Nebraska - Lincoln. 


\title{
Micromesh Fabric Pollination Bags for Switchgrass
}

\author{
K. P. Vogel,^ G. Sarath, and R. B. Mitchell
}

\begin{abstract}
Pollination bags for making controlled crosses between switchgrass (Panicum virgatum L.) plants were made from a polyester micromesh fabric with a mesh size of $41 \mu \mathrm{m}$, which is smaller than the mean reported $43 \mu \mathrm{m}$ diameter of switchgrass pollen. When used in paired-plant crosses between switchgrass plants, the mean amount of seed produced per plant was about $1 \mathrm{~g}$, or approximately 800 seeds, which was significantly greater than the 10 to 250 seeds produced previously in paired-plant crosses of switchgrass using paper pollination bags. The four- to tenfold increase in seed produced per cross enables the progeny of the crosses to be evaluated in larger numbers in genetic studies and in replicated space-transplanted or seeded sward evaluation trials. The micromesh pollination bags cost about $\$ 15$ each because of fabric costs but could be reused for 10 or more pollination seasons at an annual cost per cross of about $\$ 1.50$ or less.
\end{abstract}

USDA-ARS, Grain, Forage, and Bioenergy Research Unit, 137 Keim Hall, Dep. of Agronomy and Horticulture, Univ. of Nebraska-Lincoln, Lincoln, NE 68583-0937. USDA is an equal opportunity provider and employer. Mention of trade names or commercial products in this publication is solely for the purpose of providing specific information and does not imply recommendation or endorsement by the U.S. Department of Agriculture. Received 29 Sep. 2013. ${ }^{\star}$ Corresponding author (VogelKP61@neb.rr.com).

Witchgrass (Panicum virgatum L.), a cross-pollinated, warm-season perennial grass native to North America, is being developed into a perennial biomass energy crop. Improved crossing procedures are needed to make controlled crosses in the greenhouse for genetic studies and to effectively exploit the genetic diversity that exists in the species in breeding programs.

The inflorescence of switchgrass is a diffuse panicle 15 to $55 \mathrm{~cm}$ in length with spikelets at the end of long panicle branches (Vogel, 2004). Spikelets, which are 3- to 5-cm long, are two-flowered, with an upper perfect floret and a lower empty or staminate floret, and disarticulate below the glumes. In nature and seed production fields, pollen is dispersed by wind (Vogel, 2004). Because of the small size of the florets, making controlled crosses by emasculation is very difficult and requires a high degree of skill (Martinez-Reyna and Vogel, 1998). Previous research making controlled crosses has demonstrated that switchgrass has a gametophytic selfincompatibility system that is similar to the $\mathrm{S}-\mathrm{Z}$ incompatibility system found in other grasses (Martinez-Reyna and Vogel, 2002). Because of this self-incompatibility system, seed set from bagged panicles is typically less than $1 \%$ or nonexistent (Martinez-Reyna and Vogel, 2002; Talbert et al., 1983). Switchgrass has two principal

Published in Crop Sci. 54:1621-1623 (2014).

doi: 10.2135/cropsci2013.09.0647

(C) Crop Science Society of America | 5585 Guilford Rd., Madison, WI 53711 USA

All rights reserved. No part of this periodical may be reproduced or transmitted in any form or by any means, electronic or mechanical, including photocopying, recording, or any information storage and retrieval system, without permission in writing from the publisher. Permission for printing and for reprinting the material contained herein has been obtained by the publisher. 
ploidy levels, tetraploid $(2 n=36)$ and octaploid $(2 n=72)$ (Vogel, 2004). A postfertilization incompatibility system exists between ploidy levels in switchgrass that results in nonviable seeds when crosses are made between tetraploid and octaploid plants (Martinez-Reyna and Vogel, 2002). Because of the self-incompatibility system, controlled crosses can be made by bagging panicles from two different plants with the same ploidy level and allowing the plants to intermate, which we refer to as paired-plant crossing.

Previously, we have used Kraft or glassine type paper pollination bags, developed for use on grain crops such as sorghum [Sorghum bicolor (L.) Moench] for making greenhouse crosses by paired-plant bagging with switchgrass. Because of the large size of the switchgrass panicles, it was difficult to get panicles from two different plants into a bag and to keep most of the panicle branches inside the bag. The panicles and their branches filled the pollination bags as the panicles expanded, there was limited air circulation within the bag, and often mold developed on the panicles and florets, which adversely affected seed set and seed quality. To address this problem, we made pollination bags using polyester screening fabric with a micropore mesh size of $41 \mu \mathrm{m}$ and evaluated them for making crosses among switchgrass plants in the greenhouse. Reported pollen size for tetraploid and octaploid switchgrass cultivars averages about $43 \mu \mathrm{m}$, with a range of 38 to $50 \mu \mathrm{m}$ (Ge et al., 2011; Eckler et al., 2013)

\section{MATERIALS AND METHODS}

Polyester screening mesh with a $41-\mu \mathrm{m}$ mesh or pore size was purchased from Miami Aqua-culture, Inc. (www.miami-aquaculture.com/screen.htm). The purchased material was in $101-\mathrm{cm}$ wide fabric rolls from which $60-\mathrm{cm}$ long $\times 50-\mathrm{cm}$ wide fabric pieces were cut. Fabric glue obtained from a local textile fabric store was used to glue the long ends of the fabric pieces together to first make a fabric cylinder. Then the fabric at one end of the fabric cylinder was glued together to make the pollination bag. The completed pollination bags were $60-\mathrm{cm}$ long and $25-\mathrm{cm}$ wide and when opened had an internal diameter of approximately $14 \mathrm{~cm}$. The completed micromesh pollination bags were used to make paired-plant crosses in the greenhouse.

The plants used in the crosses were selected plants from the southern lowland tetraploid cultivar Kanlow, the upland tetraploid cultivar Summer, and plants from PI 659340, which is a northern lowland tetraploid strain that was collected in New York state. The field-grown plants were dug from nurseries and maintained in plastic greenhouse pots, which were $24-\mathrm{cm}$ deep and $27 \mathrm{~cm}$ in diameter at the top. The switchgrass plants were allowed to naturally senesce under natural light conditions during the autumn months of 2012 in an unheated greenhouse. After the plants senesced, they were trimmed to a $10-\mathrm{cm}$ stubble height and kept in the greenhouse at about $15^{\circ} \mathrm{C}$. In early December, the Kanlow plants were placed in a greenhouse section with an $18-\mathrm{h}$ photoperiod with a minimum greenhouse temperature of $24^{\circ} \mathrm{C}$. The Summer and PI 659340 plants were moved to a greenhouse section with the same light and temperature conditions in early January 2013. Kanlow plants normally flower about 4 wk later

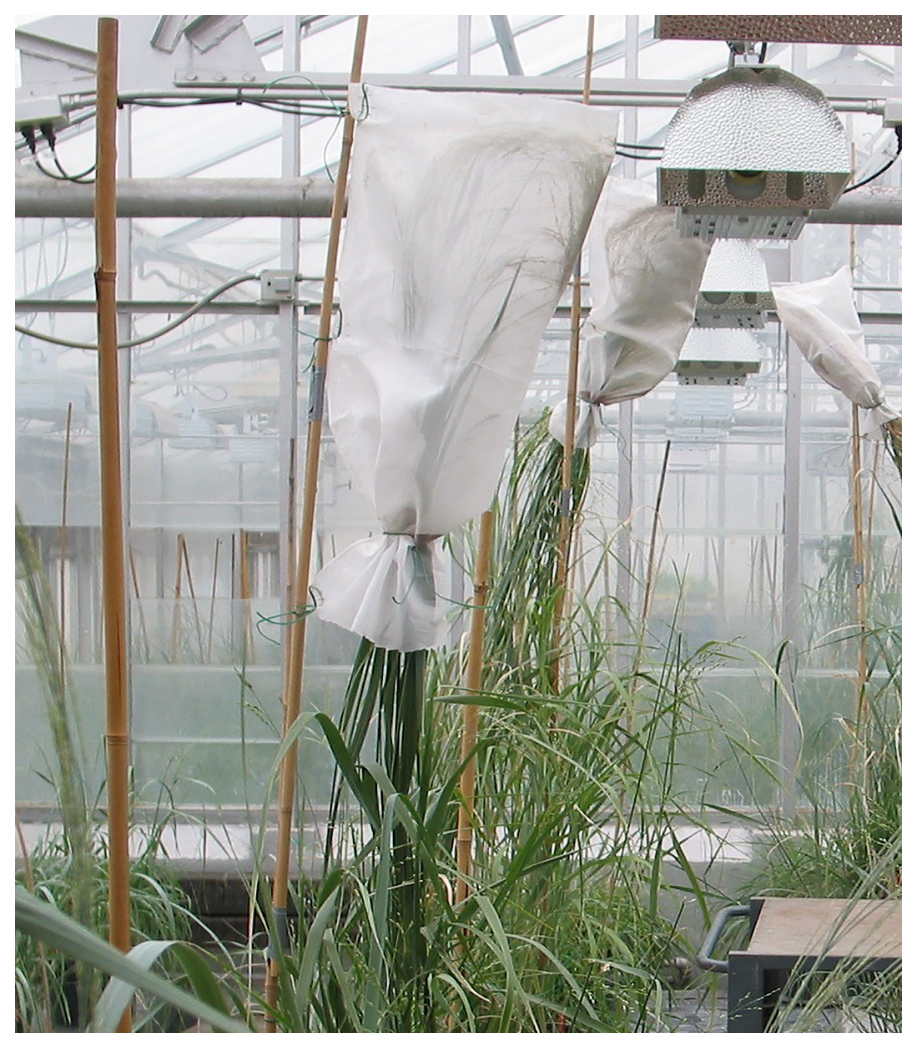

Figure 1. Micromesh pollination bags being used to make switchgrass paired-plant crosses. Panicles from two plants in adjacent pots are co-bagged inside the micromesh pollination bag. Panicles from each individual plant in a bag are removed from the bag when seed is ripe, harvested, and the seed is threshed.

than the other strains used in this study. The development of the plants was monitored, and when florets of some panicles of plants began exerting anthers on the same day, plants were paired and the panicles that were beginning to flower from both plants were mutually bagged in a micromesh pollination bag (Fig. 1). Panicle branches that had emerged anthers on the bagged tillers were removed by trimming immediately before bagging. Culms with panicles that had flowered earlier were removed or not bagged.

Three sets of paired-plant crosses were made, Kanlow $\times$ PI 659340, Kanlow $\times$ Summer, and Summer $\times$ PI $659340($ Table 1). The crosses were made between 19 February and 1 March 2013. Once panicles were bagged, fans were used to maintain good air circulation in the greenhouse, and the bagged panicles were shaken periodically between 10:00 and 14:00 when most of the anthers were shedding pollen. Bamboo poles were used to support the bagged culms of the switchgrass plants. The bottoms of the bags were tied shut using twist ties. Because of the difference in panicle height between the taller Kanlow plants and Summer and PI 659340 plants, pots of plants with the latter two strains had to be placed on blocks or buckets while the Kanlow pots were kept on the floor of the greenhouse to mutually bag panicles. It was possible to monitor the seed development process visually and by touch through the bags. Final seed ripening evaluation was done by opening the bottom of the bag and testing the seed ripeness by touch, followed by removing a few florets and examining the seed before harvest. At harvest, panicles from each individual plant in a bag were removed from the bag, harvested with hand shears, bagged in Kraft paper bags, 
Table 1. Seed quantity produced from 58 female plants in paired-plant crosses in the greenhouse using the micromesh fiber pollination bags.

\begin{tabular}{|c|c|c|c|}
\hline $\begin{array}{l}\text { Paired plant } \\
\text { crosses }\end{array}$ & Variable & $\begin{array}{l}\text { Seed weight } \\
\text { plant }^{-1}\end{array}$ & $\begin{array}{c}\text { Seed number } \\
\text { plant }^{-1 \dagger}\end{array}$ \\
\hline \multirow{4}{*}{$\begin{array}{l}\text { Kanlow X PI } 659340 \\
(28 \text { crosses) }\end{array}$} & & g & no. \\
\hline & Mean & 1.10 & 880 \\
\hline & $\mathrm{SD}^{\ddagger}$ & 1.00 & 796 \\
\hline & Range & 0.03 to 4.33 & 24 to 3467 \\
\hline \multirow{3}{*}{$\begin{array}{l}\text { Kanlow } \times \text { Summer } \\
(22 \text { crosses) }\end{array}$} & Mean & 0.91 & 731 \\
\hline & SD & 0.95 & 760 \\
\hline & Range & 0.01 to 3.16 & 10 to 2528 \\
\hline \multirow{3}{*}{$\begin{array}{l}\text { Summer X PI } 659340 \\
(8 \text { crosses) }\end{array}$} & Mean & 0.56 & 448 \\
\hline & SD & 0.46 & 368 \\
\hline & Range & 0.15 to 1.60 & 121 to 1283 \\
\hline \multirow[t]{3}{*}{ All crosses } & Mean & 0.96 & 764 \\
\hline & SD & 0.93 & 743 \\
\hline & Range & 0.02 to 4.33 & 10 to 3467 \\
\hline
\end{tabular}

† Based on 800 seeds g $^{-1}$ (Vogel, 2004).

$\ddagger \mathrm{SD}=$ standard deviation

dried on greenhouse benches until the panicles were fully dried, and then the seed was threshed by rubbing.

\section{RESULTS AND DISCUSSION}

The average amount of seed produced from the individual female parent plants was $0.96 \mathrm{~g}$ (Table 1) from the 58 different crosses, which is about 760 seeds using an average seed weight of 800 seeds $\mathrm{g}^{-1}$ (Vogel, 2004). The Kanlow $\times$ PI 659340 and Kanlow $\times$ Summer crosses produced similar amounts of seed. Smaller amounts of seed were produced on plants in the Summer $\times$ PI 659340 crosses. In all sets of crosses, there was considerable variation in the amount of seed produced per plant (Table 1). Most of the variation for the quantity of seed produced per plant within and among groups of plants was due to the number of flowering tillers that were available for paired-plant bagging on the day panicles were bagged. There is variation in time of tiller development among tillers of a switchgrass plant (Mitchell et al., 1997), and as a result, there is variation in flowering date among panicles. On some crosses, only a few tillers were bagged, while in others, 10 or more were bagged from a single plant. In most of the crosses, enough seed was produced to grow several hundred plants that could be used in genetic studies or to establish replicated, space-transplanted, full-sib evaluation plots of 10 to 20 plants (Table 1). In previous crossing seasons, only 10 to 250 seeds were produced in paired-plant crosses of switchgrass using paper pollination bags (unpublished data). The use of the micromesh pollination bags resulted in a four- to over tenfold increase in $\mathrm{F}_{1}$ seed compared with paper pollination bags. Enough seed was produced in many crosses to establish replicated, small $\left(1 \mathrm{~m}^{2}\right)$ planted sward trials, assuming a planting rate of 200 seeds $\mathrm{m}^{2}$. This is desirable because of the potential to produce $\mathrm{F}_{1}$ hybrid cultivars (Martinez-Reyna and Vogel, 2008) and the need to evaluate $\mathrm{F}_{1}$ hybrids in sward trials for biomass yields (Vogel and Mitchell, 2008). Although the mesh pore size of $41 \mu \mathrm{m}$ is greater than the smallest reported switchgrass pollen size, it is doubtful that slightly smaller pollen would penetrate the bags from the exterior because the pore area of the fabric is only about $25 \%$. Polyester screening mesh with smaller pore size is available if potential external pollen contamination is of concern. We chose to use the $41-\mu \mathrm{m}$ mesh because it provided more total pore space for air circulation than mesh with smaller pore sizes.

The use of the micromesh pollination bags also resulted in greatly improved seed quality. The micromesh fabric allowed air to freely circulate through the bags, and as a result, there was normal seed development without any mold development. High-quality seed was produced, which we used to establish replicated, space-transplanted, full-sib family evaluation trials in the spring of 2013. The bags were easy to make using the fabric glue, but they are not inexpensive because of the cost of the fabric. The cost per micromesh pollination bag for materials is about $\$ 15$, but the bags are quite durable and can be reused for 10 or more pollination seasons, which would reduce the cost to $\$ 1.50$ per bag per pollination season. Because switchgrass pollen has a life expectancy of about $1 \mathrm{~h}$, using the bags in subsequent crosses would not be a problem.

\section{Acknowledgments}

The research was funded by USDA-ARS project funds and funding from the Agriculture and Food Research Initiative Competitive Grant no. 2011-68005-30411 from the USDA National Institute of Food and Agriculture. Mention of trade names or commercial products in this publication is solely to provide specific information and does not imply recommendations or endorsement by the U.S. Department of Agriculture. USDA is an equal opportunity employer.

\section{References}

Eckler, G., T. Meyer, and C. Auger. 2013. Pollen longevity and dispersion models for switchgrass (Panicum virgatum L.). Crop Sci. 53:1120-1127. doi:10.2135/cropsci2012.06.0382

Ge, Y., C. Fu, H. Bhandari, J. Bouton, C. Brummer, and Z.-Y. Wang. 2011. Pollen viability and longevity of switchgrass (Panicum virgatum L.). Crop Sci. 51:2698-2705. doi:10.2135/cropsci2011.01.0057

Martinez-Reyna, J.M., and K.P. Vogel. 1998. Controlled hybridization technique for switchgrass. Crop Sci. 42:876-878. doi:10.2135/cropsci1998.00 11183X003800030042x

Martinez-Reyna, J.M., and K.P. Vogel. 2002. Incompatibility systems in switchgrass. Crop Sci. 42:1800-1805. doi:10.2135/cropsci2002.1800

Martinez-Reyna, J.M., and K.P. Vogel. 2008. Heterosis in switchgrass: Spaced plants. Crop Sci. 48:1312-1320. doi:10.2135/cropsci2007.12.0695

Mitchell, R.B., K.J. Moore, L.E. Moser, J.O. Fritz, and D.D. Redfern. 1997. Predicting developmental morphology in switchgrass and big bluestem. Agron. J. 89:827-832. doi:10.2134/agronj1997.00021962008900050018x

Talbert, L.E., D.H. Timothy, J.C. Burns, J.O. Rawlings, and R.H. Moll. 1983. Estimates of genetic parameters in switchgrass. Crop Sci. 23:725728. doi:10.2135/cropsci1983.0011183X002300040029x

Vogel, K.P. 2004. Switchgrass. In: L.E. Moser, L. Sollenberger, and B. Burson, editors, Warm-season $\left(\mathrm{C}_{4}\right)$ grasses. ASA-CSSA-SSSA Monograph, Madison, WI. p. 561-588.

Vogel, K.P., and R.B. Mitchell. 2008. Heterosis in switchgrass: Biomass yield in swards. Crop Sci. 48:2159-2164. doi:10.2135/cropsci2008.02.0117 